\title{
Home Is Where the Date-Palm Is: The Village as a Focus of Identity in Sudanese Fiction
}

\author{
Eiman Abbas Hassan El-Nour
}

Since its early days, modern Arab fiction has focused on issues of identity, social change and the meaning of nationhood. Writers like Naguib Mahfouz, Tawfiq al-Hakim, Suhail Idris, Yahya Haqqi, Yusuf al-Qaeed, etc., all laboured to explore in their fiction the rise of the modern nation. They often did this allegorically, but also directly, as in al-Hakim's 'Awdat al-Ruh and Mahfouz's Cairo Trilogy, where the 1919 Revolution is chronicled and celebrated.

\section{IDENTITY RECONCILED: SALIH' ViLlage}

The issues relating to national identity were explored in more detail in Sudanese poetry and early theatrical productions, since Sudanese fiction was late to develop. However, when it came of age, particularly in the work of Tayyib Salih, Sudanese fiction also found itself grappling with the difficult questions of national identity. However, Salih's writings are unique in that they appear to celebrate an identity believed already to have been at peace with itself. This is in sharp contrast to earlier poetic and other literary treatments of identity, which portrayed identity as problematic. His very choice of setting meant that he had come firmly on the side of affirming the Arab-Islamic component of Sudanese identity at the expense of the African side. His fictitious Wad-H $\square$ amid lies at the heart of the Arab north, and at least in the early writings, he attempted to portray this rural environment as a self contained and self-sufficient cultural entity. Wedding of Zein was meant to be a celebration of harmony inherent in this culture, and also the hope of reconciliation of its contradictions and conflict.

Wedding may also be read as a "national allegory", to use Frederic Jameson's term. Jameson's argument that "all third-world texts are necessarily allegorical" and need to be read as "national allegories" (Jameson, 1986: 69), may be a disputable assertion. However, with regards to Wedding, the argument that the text should be read in this way could be justified, and Jameson's assertion that, in Third World novels, "the story of the private individual destiny is...an allegory of the embattled situation of the public third-world culture and society" (Jameson, 1986:69, emphasis original) does indeed hold. The story of Zein was consciously meant as an allegory of the Sudanese nation. Like Zein, Sudan is seen as a marginal entity which will successfully reassert itself using its reserve of love and spiritual vitality, with a few miracles added for good measure. A little bit of modernisation (the make-over Zein receives in hospital) will help too.

The important thing is that the village, in the early works, achieves its unity and harmony through its own inner resources. It rejects alien influences, and accepts modernisation only on its own terms. Outside influences are absorbed in the existing framework. This pattern holds even more is so in later works. Mustafa Sa'eed has to forget or ignore all he has learned in the West to blend into the village life, and $\mathrm{D} \square$ aww atBait, the non-Muslim foreigner, is introduced to Islam, circumcised and given a local name and a wife from the village.

Religion, or at least its deeper spiritual dimension (as opposed to the formalistic creed of the imam) is central to this identity. The intense and self-effacing spirituality of al-H $\square$ anīn redeems both Zein and his enemy, Sayf al-Dīn, in one miraculous move. In the process, he also unites and redeems the village and catapults it into a new era of harmony and prosperity.

In the early short stories, and more forcefully in Season, three new elements are introduced in the picture. First, there we find the varying degrees of alienation experienced by the educated elite from traditional society. Then there is the East-West confrontation. And finally, indirectly, but very powerfully, the African-Arab dilemma of Sudanese identity is exposed under a strong light.

The very fact that identity needs to be affirmed is an indication that it is either being challenged or that it is felt to be in need of defence against threats or uncertainties. And the treatment is in fact 
constantly infused by this awareness of the tensions inherent in these assertions. While the village is the focus of this constant affirmation of identity, it is clear from the beginning that the village's claims are being addressed to the wider world outside. The presentation of the village world is even a touch apologetic, offered in the full awareness that outsiders may consider life in the village inferior. This awareness of the "other" as judge is sharply present in "Domat Wad-H $\square$ amid," where the village narrator's story is in fact a long apology for the inconvenience the young city visitor (addressed repeatedly as "my son") suffers. The village narrator's monologue starts by admitting that visitors to the village would normally not want to stay long, given that it was plagued in winter by vicious bloodsucking insects and in the summer by annoying cattle flies. The visitor, who has arrived in winter, will be no exception. "You are going to leave our village tomorrow, I am sure of it. And right you are to do so too. Why should you endure all this hardship?" (Domat Wad-H $\square$ āmid, 34). However, this very assertion is used to introduce the villagers, highlighting the central features of their identity, that they were people habituated to harsh living.

We are people whose skins are thick, unlike the skins of all other people. We are accustomed to this harsh life; in fact we love it. But we do not ask anybody else to endure the hardship of living amongst us (Domat Wad-Hamid, 34).

However, the village man insists that the visitor could not leave without being taken to see the dom tree, the village's proud symbol of identity. That was going to be the highlight of his visit.

Here it is, the dom tree of Wad-H $\square$ āmid. Look at it, soaring with its top towards the sky. Look at how its roots strike deep into the land. Look at its thick trunk, like the figure of an obese woman, and to its branches, which resemble the main of a wild mare. When the sun tilts in the afternoon, it throws its shadow from this high mound across the river, so that people on the other bank can sit in its shade. And when the sun rises in the morning, the dom tree's shade extends over the farmed land and the houses until it reaches the cemetery. Could it be a mythical eagle spreading its wings over the village and its inhabitants? ... Look at it -the dom tree- my son, towering, proud, arrogant, as if..., as if it was an ancient idol. You can see it from any point in the village. In fact, you can see it from four villages away (Domat Wad-H $\square$ àmid, 37-38).

The village is proud of its tree not only because of its imposing size, but also because of its mystical qualities, closely associated with its mythical origin.

You ask me who planted the dom tree? No one planted it, my son. Is the land where it has grown fit for planting anything? Didn't you see that it was a flat stony ground rising high above the river bank like the pedestal of a statue, with the river winding below it like a holy snakegod from ancient Egypt? No, my son, no one planted it. Drink your tea, my son; you need it after the ordeal you have just been through. Most probably, it has grown on its own. But no one remembers seeing it other than in the state you have seen it in. Our children opened their eyes and found it towering over the village. And when we go back to our childhood memories, to that dividing line beyond which we can remember nothing, we recall the dom tree standing there on a bank; beyond that, all is just unfathomable mystery. It is as if it represents the dividing line between night day. It is as if it is that faint light which is not yet dawn, but which precedes dawn... It is as though every generation which comes finds the dom tree as if it had been born with it, and it grows with it (Domat Wad-H $\square$ àmid, 3839).

No wonder, then, that dom tree not only dominates the landscape in the village, but also the consciousness and even the unconscious of the villagers. It figures prominently in their dreams. They also keep alive the myths associated with the village origins, which are in turn linked to the dom tree and to the saint after whom it had been named. The saint arrived at the site of the dom tree at a time when the whole area was uninhabited, and the village miraculously appeared. 
It is as if this village with its inhabitants, waterwheels and structures has appeared suddenly from the bottom of the earth. Liar is anyone who tells you that he knows the history of the rise of this village. Other villages start small and then grow. Ours rose up in one go. The number of its inhabitants remains constant, and its appearance remains the same. And as long as the village existed, the dom tree existed here as well. No one remembers how village appeared or how it grew, neither does anyone remember how the dom tree grew on a rocky patch high above the river bank, where it stands like a sentinel (Domat Wad-H $\square$ āmid, 37).

The topography of the village landscape is thus delineated: it is an isolated place, where life was harsh and forbidding; the people are accustomed to this way of life with its limited opportunities, even attached to it. They can understand why others may not share this attachment, and are resigned to this. But there are some aspects of their life and history, symbolised here by the dom tree and the myths and rituals surrounding it, to which they are not just attached, but of which they are proud. These myths, rituals and customs are inextricably linked to the villagers' sense of identity to such an extent that they are prepared to stand up and fight any attempt to tamper with the symbols in which they are invested. And even though they make no secret of feeling envy towards the more comfortable lifestyle of the modernised city, they are prepared to sacrifice better economic prospects for the sake of protecting their way of life.

The dom tree, with its towering figure and deep roots symbolises the pride the village feels in its traditional way of life, and the confidence in its stability. The symbolism of the deep-rooted tree as a guardian of tradition returns again in Season.

I looked at the palm tree standing in the courtyard of our house and was reassured that all was still well. I look at its strong upright trunk, its roots which strike deep in the earth, and at its green branches hanging down loosely over its top, and I feel assurance. I feel that I am not a feather blowing around in the wind but that I am, like this palm tree, a creature with a known origin, with roots and a purpose (Season, 6).

In this context, however, the previously highlighted aspects of the harsh life in the village are played down in favour of a more romantic, even lyrical depiction of the village as a haven of warmth and peace. Some of the characters, like Wad al-Rayyis make disparaging remarks about the village, which they describe as "forsaken wilderness". He is immediately rebuked, however, by Bint Majdhūb who replies: "You have not missed on enjoyment in this barren isolated place, have you? You are fat and well-shaped and do not appear to age even though you have passed the age of seventy" (Season, 8687). However, the general tone is set by the narrator's lyrical description of his homecoming at the beginning of the novel.

I returned home with intense yearning for my kin in that small village at the bend of the Nile. For seven years I have yearned for them and dreamt about them. And when I came to them it was a moment of wonder to find myself really among them. They were pleased to see me and fussed over me. In on time I felt as if a block of ice melted in my heart, as if I was a cold-stricken person who was exposed to the sun. That was the warmth of the tribe which I had long missed in those lands "whose fish die of cold" (Season, 5).

Following his momentous encounter with Sa'eed and the shocking revelations about his tumultuous past, the narrator again takes refuge in exploring the village, seeking reassurance in its familiar surroundings:

I wandered off into the narrow winding alleys of the village, with my face being caressed by the cool dew-laden breeze which blows from the north, heavy with the scent of acacia blossom and animal dung, the smell of earth which has just been irrigated after days of thirst and the scent of the half-ripe sorghum cobs and the aroma of lemon trees. 
The village was silent as usual at this hour of the night, except for the puttering of a water pump on the bank, the occasional barking of a dog or the crowing of a cock that had prematurely sensed the approach of dawn, answered by another before silence falls again....

I know this village street by street and house by house; I know too the ten domed shrines that stand in the middle of the cemetery on the edge of the desert high on top of the village. The graves too, I know one by one; I have visited them with my father, visited them with my mother and visited them with my grandfather. I know the inhabitants of these graves who had died before I was born and those who died after my birth. I have walked in the funerals of more than a hundred of them: I help with the digging of the grave; I stand on the edge of the grave among the crowd until the dead person is laid to rest on his stone cradle, and I take part on heaping the earth on them... The farms also I know, since it used to be irrigated by waterwheels, and during the drought when they were deserted by men as the fertile land turned into barren wilderness. Then the water pumps came and the men who migrated returned, and with them the land was restored to its original status, producing sorghum in the summer and wheat in winter Season, 50-51).

The search for reassurance through the affirmation of an attachment to the village is emphasised again through the symbolic role of the grandfather, who offers the link between the new identities imposed by modernity and the enduring tradition. The grandfather's home is also shown as symbolic of the village as a whole:

This large house is not built of stone or red brick, but from the very mud in which wheat is gown. It stands on the very edge of the filed, forming an extension to it. This is evident from the acacia and sunut $\square$ trees which grow in the courtyard, and plants which have sprouted on the walls themselves where water had seeped in from the planted fields Season, 75).

The greatest reassurance is offered by the grandfather himself as the living embodiment of a resilient and beloved cultural tradition.

I lingered by the door as I savoured that sweet sensation which precedes the moment of my encounter with my grandfather each time I returned from a journey. It is first a pure sense of wonder that this ancient being could still exist on the face of the earth. When I embrace him I savour that unique smell of his, a blend of the smell of the great shrine in the cemetery and the smell of a newborn baby. That shrill and confident voice of his represents a bridge between the uncertain moments which have yet to take shape, and the moments whose events have taken place and were comprehended, becoming bricks in an edifice a certain significance and meaning. We are poor peasants by the standards of the European industrial world, but when I embrace my grandfather I feel an immense richness, as if I am a note in the heartbeats of the very universe. He is no towering oak tree with luxuriant branches growing in a land on which nature has bestowed water and fertility, but he is like the sayyāl bushes in the deserts of the Sudan, with their sharp thorns and thick bark; they defeat death because they do not live too extravagantly Season, 77).

This passage sums in a nutshell the perspective taken in Salih's work on the issue of identity. Here, the apparent contradiction between the pride in belonging to the village and the acute realisation of the downside of this attachment. This twin motif of self-deprecation and pride is highlighted explicitly in two related passages in D $\square$ aww atBait. In the first, al-T $\square$ āhir Wad atRawwāsī and Mih $\square$ aimīd's other friends question the wisdom of his decision to return to "miserable" Wad-H $\square$ āmid, which meant that he was either "a poet, a madman or someone who had become prematurely senile." Wad alRawwasi speaks for the rest. 
Wad-H $\square$ amid is a miserable place. In summer, its heat is unbearable, and in winter, may God protect you from its cold. It is afflicted with the nimitta winter insects at the time of the pollination of date palms, and flies at the time of the ripening of sorghum. It has snakes and scorpions, malaria and dysentery. Its life is miserable, and its problems more numerous than the hair on one's head ( $D \square$ aww at Bait, 86).

In the second passage Mah $\square$ mūd, the village elder, explains the village ways to $\mathrm{D} \square \square$ aw aABait the ways of the village as he was being initiated into them.

Servant of God, as you can see, we live under the protection of the All-Powerful Judge. Our life is all toil and hardship, but our hearts are full of contentment, and we accept what God has ordained for us. We perform the obligatory prayers and protect our honour; we stand ready to face any calamity or eventuality destiny may throw our way. We do not show conceit in times of plenty, and we are not unduly disturbed in times of hardship. Whatever little we have, we have acquired by our labour. We have robbed no one of what is rightly his, nor did we accept the fruits of usury or unlawful gain. We are people of peace in the time of peace, and of anger in the time of anger. Those who do not know us would think that we are so weak that a breeze of wind could topple us over; in truth, we are like the $\mathrm{h} \square$ arāz acacia trees growing in the fields (D $\square$ aww atBait, 112).

Similar sentiments were expressed to $\mathrm{D} \square$ aww atBait by $\mathrm{H} \square$ asab atRasūl who was the first to receive him when he emerged from the river just before dawn. "A thousand welcomes, stranger arriving from God's land," he greets the stranger, as he prepares to extend hospitality to him even though his family was destitute. "You have reached the guests' dining place and resting place of the weary" (D $\square$ aww atBait, 104).

There is always ambiguity about whether the people are proud of themselves in spite of their poverty and perceived marginalisation, or because of it. However, there is clearly an acute awareness that the village's topography and living conditions are intimately intertwined with the villagers' sense of identity.

\section{Conflict AND Collective IDENTITY}

The focus of the village as the anchor of collective identity does not overlook the fact that the village community does experience internal conflicts. In Wedding, which represents the most determined attempt to portray and celebrate harmony in the village, the novel starts by highlighting points of conflict and tensions over the exercise of authority (the headmaster versus Tiraifi), over economic issues ( $\mathrm{H} \square \overline{\mathrm{j} j}$ 'Alī, the shopkeeper, versus Shaikh 'Abd atS $\square \square$ amad, his creditor, or $\mathrm{H} \square$ alìma, the milk seller versus her customers) and over social relations (Sa'adiyya, Ni'ima's mother, versus Āmina, the mother of a spurned suitor). This latter feud is particularly illuminating, since it reveals how the daily acts and gestures of solidarity which bind the community together could function as points of tension. The two women had not been on speaking terms for months over mutual allegations of neglect of social courtesies (Sa'adiyya failed to present her condolences following the death of Amina's mother, because she was ill at the time. A dispute then erupted over who should fulfil her customary obligation first). Feuds like this occur frequently in traditional society, even though such courtesies are supposed to promote solidarity and social cohesion.

The primary divisions in the village are those which ran across lines of kinship or social stratification. The village community incorporates within it various groups which endure varying degrees of marginalisation. First, one encounters the Goz settlement on the edge of the village. The Bedouins who inhabit the settlement are treated as outsiders, and looked down upon. They in turn regard themselves as "pure" Arabs who are superior to their host community. Intermarriage is rare, and the settlers are economically underprivileged, since they do not have direct access to land, working mainly as labourers in the fields and palm groves. Another settlement on the edge is populated by gypsies, whose interactions with the village are even more restricted. Lower still down the social ladder are former slaves. Some of these live on the margin of society in the village, even though their 
existence is precarious as is demonstrated by the case of Mūsā the Lame, who was thrown out of his former master's home by the latter's son. Of interest in this category are the ex-slave women of the alWāh $\square$ a, who survive in a precarious settlement on the edge of the village (literally and figuratively), mainly by selling forbidden pleasures: sex, drink and merriment. They suffer not just rejection, but active persecution. Their homes are frequently burnt down, and the imām continuously rails against their "sin and corruption". If they dared to come to the village in order to participate in celebrations or public gatherings, they could face serious adverse reactions, as happened when Mah $\square$ jūb and his gang beat them up and threw them out at a wedding.

Other features of stratification and differentiation are also apparent, as indicated by the narrator's grandfather's jibe at the clan of $\mathrm{H} \square$ usna, who were derided for not being discriminating enough in choosing husbands for their daughters.

Economic conflict and exploitation is a more frequent feature of village community, and it figures prominently in Salih from "Nakhla 'alā al-Jadwal", and "H $\square$ afnat Tamr". Such conflicts are also closely intertwined with social conflicts over status. While kin solidarity and good neighbourliness were supposed to mitigate economic conflict by enhancing community solidarity, this has not always been the case. In later works, the collapse of the "natural order" of things is signified by the weakening of traditional bonds and the upsetting of traditional hierarchies in favour of naked economic power. This is symbolised most blatantly in the rise of Sa'īd 'Ashā al-Baytāt (aka Sa'īd alBūm) from the status of a marginalised and despised figure to a grudgingly accepted figure in community. His instrument of rise was intrigue and open blackmail. He ensnared the headmaster into indebtedness to him, and then blackmailed him into accepting him as a husband for his daughter. It is true that he did use other means, such as family and clan connection (the headmaster's wife hailed from his tribe), but he was the first to acknowledge that it was the money the headmaster owed him that tipped the scales in his favour. When he first put the proposition of marriage the headmaster exploded in anger at the insolence of such an outrageous proposal. "Are you out of your mind?" The headmaster blasted in a fit of rage. "Do you think that the country has no laws? You, the dirty and smelly Sa‘īd think that you can marry my daughter?" (D $\square$ aww atBait, 30). But in the end, he was

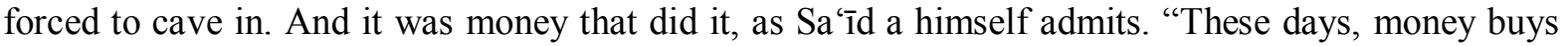
not just Fat $\square \mathrm{t} \square$ üma [the singer]; money can in fact harness the wind itself" (D $\square$ aww aBait, 26). And again: "What headmaster? I don't give a hoot about the headmaster or even the 'Umda. I have money. I swear these days if I wanted to marry the "Umda's daughter I would do so" (D $\square$ aww at Bait, 33).

Sa'îd's unexpected rise to respectability is closely connected to the subversion of political authority, another focus of local conflicts. He played a central role in engineering the "coup" which removed Mah $\square$ jūb and his "gang" from power. The speech he gave at the general meeting of the village's cooperative society was unexpectedly incisive, and it swayed opinion against the dominant group. While admitting that Mah $\square$ jūb and his friends were admirable and indispensable pilars for society, he told the meeting that they had benefited enough from their positions of leadership and time has now come for them to step down and give way to others.

The conflict which toppled Mah $\square$ jüb and his group revealed new cracks in the façade of village solidarity, this time one which ran along the generation gap. The revolt was led by the younger generation, directly affected by modernisation and the new schools. This caused bitterness among those removed from power by the revolt. As one supporter of the old leadership put it:

Our sons have turned against us. The schools which we have built through toil and running here and there produced kids who now argue glibly against us. It seems that the village had fallen into chaos under our feet while we were fast asleep (D $\square$ aww atBait, 112).

It turns out that their enthusiasm for modernisation was not far-sighted enough as far their interests and their grip on power were concerned. It is interesting that the lines of authority in the village are not always clear. Traditional authority is represented by two main groups: the elders and notables represented by people like the narrators' grandfather at one level, and the "gang" who appear to wield actual power at another. Some other centres of power are mentioned, but not given prominence: the 'umda, the imām and various government officials. The forces of rebellion are led by the irreverent young. In the early works such as Wedding, this rebellion takes mainly the form of defying religious authority as represented by the imām, and traditional authority represented by the village's customs 
and norms of decency. In later works, rebellions take a more serious form, becoming more political in nature; but there is no overt defiance of religious and customary norms. In fact, the girls who lead the demonstrations against the elders are careful not to overstep the norms when it came to dress or language, and this is duly noted by the community.

The subversion of authority is a recurring theme in Salih, and it takes various forms which are not often successful. At times, figures of rebellion are re-integrated in the community, as was the case with Sa'īd 'Ashā al-Baytāt, Sayf al-Dīn or Bakrī, becoming in turn figures of authority. At times, as in the case of Zein, the rebel becomes the instrument of the reintegration and reconciliation of the village community.

The integration and cohesion of the village community and the cementing of its common identity is also mediated by allegiance to common values and social norms. In particular, the values of generosity, hospitality and solidarity are highly prized. The villagers' often pride themselves in facing adversity in dignity, sharing what little they have with each other and with strangers. Mah $\square$ jūb and his "gang" are praised for being "people you can rely on in adversity and good times" (D $\square$ aww at Bait, 63). Mustafa Sa'eed is equally praised for regularly attending the Friday prayers are for being quick to offer assistance "with his money and his person in happy and sad occasions" (Season, 10).

It is interesting that religious observance is only regarded as essential for the acceptance of strangers, but not so for the "original" inhabitants. Mah $\square$ jūb and his gang are accepted as leaders even though none of them ever steps into the mosque except for purposes that have little to do with religious motives. But the gang regards itself nevertheless as the guardian of the moral order, as seen in its hostility to al-Wāh $\square$ a inhabitants and the way it imposesthose norms through violence when needed. However, there are certain transgressions against core social norms closely linked to the village's sense of identity that could lead to instant ostracism. Sayf al-Dīn's decision to marry his al-Wāh $\square$ a girlfriend was one such cardinal sin that led his father to disavow him and force him to leave the village. His was not a transgression against religious values, since it was a graver sin in religious terms to live in sin with his girlfriend than to marry her. However, the marriage of the son of a village notable to an ex-slave girl with questionable reputation was seen as a frontal attack on the social fabric that sustained the community and its sense of identity. This was absolutely unforgivable.

Religion, on the other hand, could be the avenue for social integration for strangers and individuals regarded as marginal or inferior. The case of Bilāl, the ex-slave who rose to prominence because of his reputation as a renowned mystic, is an illustration of this. Bilāl's friendship with Shaikh Nas $\square$ r Allāh wad $\mathrm{H} \square$ abīb helped overcome his marginality in the same way as Zein's friendship with Shaykh al-H $\square$ anīn helped him overcome his. Nevertheless, it would still have been unthinkable for Bilāl, saintly and revered though he was, to marry a girl from the established families of the village. His marriage to $\mathrm{H} \square$ awwā' bint at 'Iraibī, herself an outsider living alone following the early death of both her parents, however, was a further step in the integration of his descendants into the community. His son, al-T $\square$ āhir, became a full member of the community to the extent of becoming a leading member of the "gang".

Certain mystical events and the myths surrounding them also became constitutive of the village's sense of identity. The founding myth of Wad-H $\square$ amid and the sacred qualities of its dom tree were at the centre of this web of myths and memories. al-H $\square$ anin's miraculous intervention to save Sayf at Dīn and the series of miraculous transformations that followed it became the starting point of a process of reintegration and reconciliation, some form of "second birth" for the village, an additional founding myth that eventually reaffirmed and celebrated its unity in the symbolic wedding.

The unity and self-assurance of the village were shattered by other traumatic or mystical events such the suicide of $\mathrm{H} \square$ usna or the calamity that befell the family of BandarShāh. But this unity was again reaffirmed through new unifying mystical experiences such as the mysterious visions which brought the whole village together at the dawn prayers following the night of Maryam's burial, or experiences of the morning of Bilāl's death when he made his last call to prayers. On these occasions, the adhān (call to prayer) became a mystical event in itself, a call which resonated with the villagers' deepest aspirations and fears.

The voice of Sa'īd al-Būm as heard by Mih $\square$ aimīd at that hour, while he was half awake and half asleep, was like a magnet to which the dust of unfulfilled dreams had hung, giving it depths and dimensions 
it did not possess... He jumped out of bed, did his ablutions and left home with the cold winter winds blowing in his face and almost pushing him back. He had no idea why he did that, for he had not performed the dawn prayers in the mosque for thirty years or more... He walked towards the mosque as his grandfather used to do, as if that call on that dawn had been addressed to him alone and no one else; as if there was a debt that had to be paid; as if he was finally performing a role for which he had been prepared, and from which he had been running away all those years. Arriving in the mosque, he found it brimming with worshippers. He was surprised at first and asked 'Abd al-H $\square \bar{a} f \grave{z} \square \square$ whether that gathering was because a great thing has befell the village. He said: "God guides whom He wills."

... The imām recited al-D $\square \mathrm{u} \square \mathrm{h} \square \overline{\mathrm{a}}$ (MidMorning) chapter with a resounding voice which drew its force from the sadness of those men who came together that dawn for no clear reason and without an appointment. 'Abd al-H $\square$ âfîz $\square \square$ was crying, alone at first; then he was joined by Sayf al-Dīn, then Sa'īd 'Asha al-Baytāt and then Mah $\square$ jūb. Under the burden of all this, Mih $\square$ aimīd vacillated between doubt and certainty: when he bows, he feels that he had arrived, and when he prostrates, he discovers that his heart was completely empty. Then the weeping engulfed the lot, and the waves carried the recited verses, verse by verse, fluttering on the surface like banners (D $\square$ aww atBait, 53-55).

These deep mystical experiences unite as well as divide. But mostly they unite by virtue of being shared. Even this uniting experience, however, impacts the participants differently.

\section{The Village AND THE OUTSIDE WORLD}

The village identity is affirmed in the face of the outside world and is constituted in dynamic interaction with it. First, the village is defined by its geography and topography. Its location is a vital aspect of its identity.

[The village] looked to him from that distance as if stood on vast and limitless plateau, exposed like a person sleeping in the open, without a cover: the northern bank, bright yellow, glistening under the midmorning sun; then the river, appearing intermittently, like a mirage, like a flash of lightening. The $\mathrm{s} \square$ unut $\square$ and $\mathrm{t} \square$ alh $\square$ acacia trees, clinging to the water, are adjacent to the wheat fields. And when his eyes rest on the palm groves in the middle, he is taken by the zest of life they display. Other fields extend to the bottom of the houses, and after that, sand and endless desert. It looked to him as if it was hanging in empty space: it comes so close as to appear within reach, and then to hastens away from him like an impossible dream (Maryūd, 32).

But while the village is an isolated entity, it still exists within a wider social milieu, which rises in solidarity with it during its famous celebrations, as in the famous weddings of Zein, Sa 'îd 'Asha alBaytāt, or D $\square$ aww atBait. The latter was a "well attended occasion" which brought people from far and near. The lyrical depiction of the coming together of the people to celebrate sums up the whole notion of primordial unity of feelings and values.

People were few at that time, living in scattered villages, whose lights appeared in the night as if they were hanging in the sky. The sounds reach from bank to bank only faintly and barely audible. But they would know about events across the river as if invisible bridges existed between the two banks of the river. They would know who had irrigated his field in the night, and who had done so during the day; who was ill, who was born, who died and who got married; who sold and who bought. They were linked together by kin relations and 
by marriages, and they come together in markets and business deals. They exchange seeds, date palm seedlings and studs of cattle and donkeys. They are united through maddāh $\square$ in, singers and reciters of the Quran. This is how things are from the meeting point of the two rivers to well beyond the borders of Egypt. It is no wonder then that they have all heard about the big celebration in Wad-H $\square$ ammid and flocked to it: from up and down the river, from north and south, by boats across the river, or by donkeys or on foot, carrying their presents: dates, wheat, barley, beans, onions, butter and fat. Each according to his means: this man carrying a rooster, and that a lamb or kid goat. They come scattered like drizzle, and then they quickly come together and join in a great torrent teaming with a new life which is broader and greater than the sum of its parts ( $D \square$ aww at Bait, 124).

In these celebrations, all the antagonisms referred to earlier momentarily dissipate, and the unity and solidarity of the community is affirmed and extended to include all and to extend to wider horizons. Other linkages are also forged through other channels. The holy men of the village link it to wider communities, and sometimes directly to the supernatural. (Strange figures and hordes of unknown origin are said to appear at certain critical moments and join the villages celebrations or ceremonies, as was the case at the funeral of Bilāl al-Rawwāsī (Maryūd, 49). There were also more mundane linkages to the external world, as in the case of Mah $\square$ jūb's membership in National Socialist Democratic party, which happened to be the ruling party at that time.

Migration was another avenue of interacting with the outside world, and one of the most traumatic. Emigration is imposed on the young of the village mostly by the hardship and limited opportunities available. In "Nakhla", we find the separation of Mah $\square$ jūb from his elder son, who went to seek work in Egypt, and his daughter, whose husband lives far away in the centre of the country, a major cause of anguish for him. But the separation is more painful since no economic benefit had accrued from this painful separation. While Mah $\square$ jūb is angered by the fact that his son does not even write, the reader could surmise that the young man himself may have also been suffering, perhaps finding it difficult to get a decent job. In "Domat Wad- $\mathrm{H} \square$ ammid", the village narrator reveals that his son had run away to the city to seek education. While this is another indicator of tension in the village community which appears to be torn apart by the pressures of modernisation and the aspirations it generates, the narrator himself regards it as a hopeful sign. The new generation could be the agent of a more constructive form of modernisation, one which would enable the village community to benefit from modernisation without losing its soul in the process.

That this was an overly optimistic expectation was indicated early, starting from the story "Risāla ilā Ilīn", where the themes of divided loyalties of those touched by modernisation are explored. This theme is implicit in most stories, where the perspective of the modern educated elite is often a privileged one, either directly, through being adopted by the narrator, or indirectly, with the narrative being structured for the benefit of an audience deemed to be predominantly modern. In "Domat Wad$\mathrm{H} \square$ āmid", for example, the narrator, presented as the authoritative voice of the village, is in fact telling his story for the benefit of his partly "invisible" one-man audience, a visiting city man. The theme of the alienated modern educated individual seeking to relate to the village environment as an "outsider" appears to be a dominant motif.

In "Risāla ilā Ilīn", the process is carried a step further, and this time we observe the protagonist experience a sense of alienation from his village community and adopt the perspective of an outsider. Following his monologue in his letter to his Scottish wife, he experiences a sudden and acute awareness of the progressive loss of sense of belonging to his folks.

These people are his people, a large tribe of which he is a member. Nevertheless, they are now strangers to him and he is a stranger to them. A few years back, he was a living cell in the cohesive body of the tribe. When he departs, he leaves a vacuum that cannot be filled until his return (Domat Wad-H $\square$ āmid, 31). 
This time, however, he does not find their exaggeratedly warm greetings reassuring, and fears that it may be a sign that their feelings of natural affection towards him have waned. He is deeply disturbed by the growing gap between him and "his people", although there is no indication that anything could be done to bridge it.

In Season, Mustafa Sa'eed presents both the extreme sense of alienation and the futile attempt to overcome it by complete re-absorption into traditional society. He had earlier also entered into an intense relationship with Western society, trying to blend into it at one level, with some success, and entering into violent conflict with it at another level. The narrator in Season, on the other hand, sits astride the two cultural worlds, somewhat uncomfortably, but with an appearance of being better reconciled to life's realities. He identifies strongly with his village community, even though he is able to abstract from it and view it from the outside, sometimes critically. He feels no particular animosity towards the West, and no attachment either.

But as the story progresses, the narrator reveals a sense of loss of identity and loss of confidence in himself and his roots: "I am now alone, no escape, no refuge, no guarantee. My world had a wide extension outside, but it has now receded and shrunk until I became the world and there is no world but me. Where are the ancient roots deep in history? Where are the memories of life and death? What happened to the caravan and the tribe?" (Season, 135). This loss of balance following the disaster of $\mathrm{H} \square$ usna's suicide, did not only affect the narrator, but the whole village. Nothing like this had ever happened before, they kept saying. The village later recovered its balance somewhat, taking refuge in its traditional solidarity, and attempting to blot out the catastrophic event by throwing a veil of silence over it. The narrator also recovers a tenuous balance at the end, but only by resigning himself to the utter meaninglessness of life.

Thus in spite of his reasonably adjusted stance, the narrator does not accept that the identity crisis had been resolved, and shifts the burden for achieving this on the following generation. This is another recurring theme, where the resolution of the crisis of incomplete modernization is shifted on a generation that has yet to appear, one which would have resolved the identity problem within itself first. In $\mathrm{D} \square$ aww atBait and Maryūd, the turmoil continues, and the old power relations are upset in a succession of upheavals, but the bedrock of solidarity is again provided by love and religion. The saintly Nas $\square$ fAllāh Wad-H $\square$ abīb takes the place of al-H $\square$ anīn in Maryūd, and mystic visions redeem and unite the community again.

The outside world and its relation to the village was touched on in several other places. Other parts of Sudan are referred to as neighbouring territory, as centres of power impinging on village life. They are also treated equally with other far away places as places of exile. The South is mentioned only in passing, as when Sa'eed's mother is said to belong to a Southern tribe, or as the source of exotic goods (Maryūd, 16). However, the South is not directly related to the community of marginalised exslaves in the village, many of whom would have southern ancestry. Interestingly also, some parts of Sudan (in the East and West) are referred to as mysterious and dangerous sources of seduction. During his wayward days, Sayf al-Dīn is said to have travelled to those parts to indulge his dissolute lifestyle. These regions are in this regard associated to well-known foreign haunts of fun seekers, such as Asmara, the capital of neighbouring Eritrea, Egypt and, of course, Europe. These places are there as symbols of alternative (and subversive) lifestyles that are perceived as threats to the village's traditional ways. They also refer to city life in general, which is treated as seductive and subversive mainly because it offers an easier and more attractive lifestyle, and one with less moral inhibitions. Even nearby towns such as Marawi are revealed to be sources of seduction, as shown by the story of Zein's flirting with the nurses during his short stay at the hospital. However, the most enduring and haunting of all contrasts is that between East and West. The contrast between the two worlds sums up all the contradictions which threaten to undermine the village's sense of identity. It sums up the other related contradictions: city versus village, tradition versus modernity, African versus Europe, Islam versus the West, Colonised versus Coloniser.

\section{AUTHOR'S BIOGRAPHY}

Eiman El-Nour, is Associate Professor in English Literature at Neelain University and Ahfad University, and Teaching Fellow at Khartoum University. She is also Fellow of Wolfson College, Cambridge. She specialises in teaching African Literature and her main research themes include African women's writing, Sudanese literature and Sudanese orality. She is author of Hadha Huwa alMakan!: Fi Tadhakkur al-Tayyib Salih (This is the Place!: Remembering Tayeb Salih) (2010). 